\title{
Egg Development and Larvae and Juveniles Morphology of Carp, Cyprinus carpio in Korean
}

\author{
Jae Min Park ${ }^{1}$, Seong Jun Mun ${ }^{1}$, Hu Sun Yim ${ }^{1}$ and ${ }^{\top K y e o n g}$ Ho Han ${ }^{2}$ \\ ${ }^{1}$ Gyeongsangbuk-do Native Fish Business Center, Uiseong 37366, Korea \\ ${ }^{2}$ Marine Technology Undergraduate, Chonnam National University, Yeosu 59626, Republic of Korea
}

\begin{abstract}
This study was conducted to observe egg and larvae morphological development of carp to obtain basic data for resource conservation and taxonomic research. Brood carp used in the research (total length 67.3-75.5 $\mathrm{cm}$, average $71.0 \pm 3.45 \mathrm{~cm})$ were bred in a circular rearing aquarium $(600 \times 300 \times 100 \mathrm{~cm})$ using a running water system from January to July, 2015 . Breeding water temperature was maintained at $23.0-25.0^{\circ} \mathrm{C}$ (average $24.0^{\circ} \mathrm{C}$ ). Fertilized carp eggs were translucent and globular, and their size was $1.75-1.89 \mathrm{~mm}$ (average $1.82 \pm 0.06 \mathrm{~mm}$ ). Blastoderms formed $10 \mathrm{~min}$ after fertilization and reached the two-cell stage $30 \mathrm{~min}$ after fertilization. Then, the embryo turned dark and exhibited melanophores, and blood started flowing from the heart across the egg yolk at $42 \mathrm{hrs}$ and $50 \mathrm{~min}$ after fertilization. Hatching began $70 \mathrm{hrs}$ and 26 min after fertilization larvae emerged through the egg membrane, starting from the head. The length of prelarvae immediately after hatching was 5.23-5.38 $\mathrm{mm}$ (average 5.31 $\pm 0.11 \mathrm{~mm}$ ) the mouth and anus were closed, and the pectoral fin was formed. Postlarvae at 18 days after hatching had a total length of 11.9-13.9 mm (average 12.9 $\pm 1.40 \mathrm{~mm}$ ), separate anal fin and back membranes, and fin ray. Juveniles fish at 35 days after hatching had a total length of 29.9-30.2 $\mathrm{mm}$ (average 30.1 $\pm 0.13 \mathrm{~mm}$ ), with the body covered with scales, and the same number of fin rays, color, and shape as their broodstork.
\end{abstract}

Key words : Carp, Cyprinus carpio, Egg development, Juveniles, Larvae

\section{INTRODUCTION}

Cyprinus carpio belongs to Cypriniformes, order $\mathrm{Cy}$ prininae, which also includes Carassius auratus, C. curvieri, Israeli carp C. carpio, and Ctenopharyngodon idellus, comprising three genera and five species (Kim et al., 2005).

The history of carp was first documented in 500 B.C. by Fan Li in China through his book Yaneogyeong on fish culture technology. Carp farming in Korea started seriously with the establishment of a national fish farm in Jinhae in 1929 (Aquaculture, 2009).
Carp color, shape, and habits differ according to the region and environment; therefore, there is extensive research being conducted to improve their breeds (Kang, 1990). Previous carp research in Korea included the development of black carp (Kim et al., 1999), genetic comparisons of C. carpio and C. curvieri (Yoon \& Park, 2006), morphological variations (Nam et al., 1989), and egg and larval morphological development (Han et al., 2001a), and global research included multi-species aquaculture systems (Azim \& Wahab, 2003), growth hormones (Cook et al., 1982), and viruses (Chen et al., 2008).

\footnotetext{
Manuscript received September 16, 2017, Received in revised form September 19, 2017, Accepted September 23, 2017

$\dagger$ Corresponding Author : Kyeong Ho Han, Department of Aqualife Science, Chonnam National University, Yeosu 59626, Korea. Tel: +82-61-659-7163, Fax: +82-61-659-7169, E-mail: aqua05@jnu.ac.kr

This is an Open Access article distributed under the terms of the Creative Commons Attribution Non-Commercial License (http:// creativecommons.org/licenses/by-nc/3.0) which permits unrestricted non-commercial use, distribution, and reproduction in any medium, provided the original work is properly cited.
} 
Carp is the main species used in freshwater fish production. However, water pollution in rivers and dams has increased owing to domestic and industrial sewage. Therefore, carp production has decreased considerably since cage culture was prohibited as a part of a protection policy for drinking water sources. Further, ecological damage has increased owing to the introduction of exotic fish. Therefore, there has been an increased interest in seed production and fish release projects to recover these resources (Aquaculture, 2009; Han et al., 2001a).

Research on the initial life cycle of fish is fundamental for understanding the biological characteristics of the species; thus, phylogenetic systematics of similar species is important. Initial life cycle research is particularly important concerning freshwater fish to restore species and resources, since the numbers of fish and habitats are both decreasing (Blaxter, 1974; Kim et al., 2012).

Initial life cycle research on carp include the following species: Rhynchocypris oxycephalus (Han et al., 1999), Pseudopungtungia nigra (Lee et al., 2004), Gobiobotia macrocephala (Ko et al., 2011a), G. brevibarba (Ko et al., 2011b), P. tenuicorpa (Ko et al., 2012), Microphysogobio koreensis (Kim et al., 2012), and Zacco koreanus (Lee et al., 2013).

Carp life cycles have been reported in inland water culture journals and aquaculture-related books, but limited research on egg development processes and larval morphological development has been briefly reported by Uchida (1939).

Therefore, this research aims to investigate carp egg and larval morphological development as part of initial life cycle research to provide basic data for resource conservation and taxonomic research.

\section{MATERIALS AND METHODS}

\section{Brood stork culture}

Brood (total length $67.3-75.5 \mathrm{~cm}$, average $71.0 \pm 3.45 \mathrm{~cm}$ ) used in the experiment were bred in a circular rearing aquarium $(600 \times 300 \times 100 \mathrm{~cm})$ made from polyvinyl chlo- ride (PVC), using a running water system from January to July, 2015. Extrusion pellets were used as feed, which was given twice a day. Breeding water temperature was maintained at $23.0^{-}-25.0^{\circ} \mathrm{C}$ (average $24.0^{\circ} \mathrm{C}$ ). The temperature was increased to $26.0^{-}-27.0^{\circ} \mathrm{C}$ (average $26.5 \pm 0.05^{\circ} \mathrm{C}$ ) to induce spawning, and an artificially produced spawning tank was installed in the aquarium to induce natural spawning to harvest fertilized eggs.

\section{Egg development processes and larval morpho-} logical development

Fertilized eggs were placed in a $500 \mathrm{~mL}$ glass beaker, and the breeding water temperature was maintained at 23.0$25.0^{\circ} \mathrm{C}$ (average $24.0^{\circ} \mathrm{C}$ ). The number of eggs was reduced by half twice a day. The egg size of 50 randomly selected eggs was measured using a phase microscope (Leica microsystem EZ4HD, Germany). The egg size was measured nearest to $0.01 \mathrm{~mm}$.

Larvae were placed in a circular PVC aquarium (600× $300 \times 100 \mathrm{~cm}$ ) with a still-water system and aeration to provide oxygen immediately after hatching. Larvae at $10 \mathrm{~d}$ after hatching were fed 4-5 artemia (nauplii of Artemia sp.) per $\mathrm{mL}$, and larvae 10-30 days were fed 2-3 freshwater fleas (Daphnia similis) per $\mathrm{mL}$.

Larvae morphological development processes were observed daily in five larvae under anesthezia (MS-222, Ethyl 3-aminobenzoate methanesulfonate, Sigma Aldrich Co., St. Louis, USA) after hatching using a stereoscopic microscope (Nikon SMZ18, Japan), measured to the nearest 0.01 $\mathrm{mm}$. The stages of larvae morphological development were categorized according to Kendall (1984).

\section{RESULTS}

\section{Egg shape}

Fertilized eggs were translucent and globular, and did not exhibit an oil globule. Egg length was $1.75-1.89 \mathrm{~mm}$ (average $1.82 \pm 0.06 \mathrm{~mm}$ ) (Fig. 1A). The surface of the egg 
was covered with a highly adhesive phlegmatic material.

The demersal eggs sank underwater.

\section{Egg development processes}

The blastoderm formed 10 min after fertilization (Fig. 1B), and reached the 2-cell stage $30 \mathrm{~min}$ after fertilization (Fig. 1C), and 4-cell stage after fertilization (Fig. 1D). The egg reached the 8 -cell stage $1 \mathrm{hrs}$ and $50 \mathrm{~min}$ after fertilization (Fig. 1E), 16-cell stage $2 \mathrm{hrs}$ and $30 \mathrm{~min}$ after fertilization (Fig. 1F), 32-cell stage $3 \mathrm{hrs}$ and $10 \mathrm{~min}$ after fertilization (Fig. 1G), and 64-cell stage $3 \mathrm{hrs}$ and $50 \mathrm{~min}$ after
A

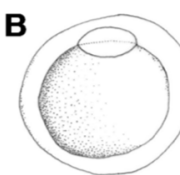

E

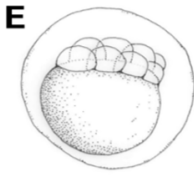

$\mathbf{F}$
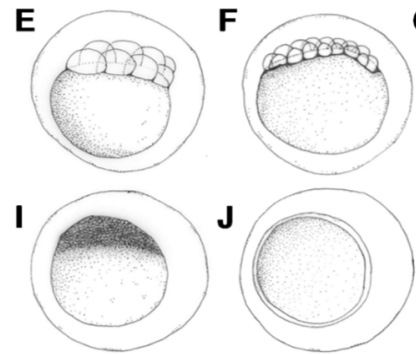

M

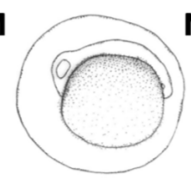

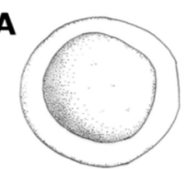

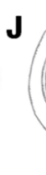

$\mathbf{N}$

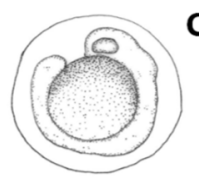

c

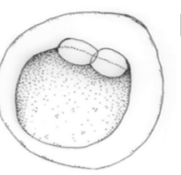

G

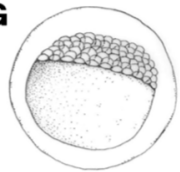

K

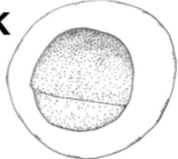

0

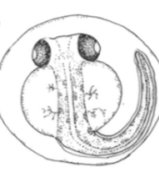

H
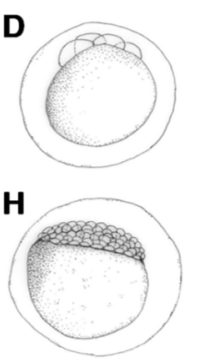

$\mathbf{L}$

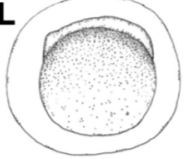

$\mathbf{P}$

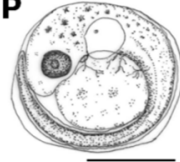

Fig. 1. Egg development of carp, Cyprinus carpio. A: Fertilized egg; B: Blastodisc, $10 \mathrm{~min}$; C: 2 cells, 30 min; D: 4 cells, 1 hrs 30 min; E: 8 cells, 1 hrs 50 min; F: 16 cells, 2 hrs 30 min; G: 32 cells, 3 hrs $10 \mathrm{~min}$; H: 64 cells, 3 hrs 50 min; I: Morula stage, $4 \mathrm{hrs} 10 \mathrm{~min}$; J: Blastula stage, 5 hrs $20 \mathrm{~min}$; K: Gastrula stage, 6 hrs 40 min; L: Formation of embryo, 11 hrs 45 min; M: Formation of Kupffer's vesicle, $20 \mathrm{hrs} 7 \mathrm{~min}$; N: Appearance of melanophores in the eye and disappearance of Kupffer's vesicle, $22 \mathrm{hrs} 10 \mathrm{~min}$; O: Heart beating at $68-70$ per min and appearance of melanophores in the yolk, 42 hrs 50 min; P: Embryo immediately before hatching, $70 \mathrm{hrs} 26 \mathrm{~min}$. Scale bar $=0.5 \mathrm{~mm}$. fertilization (Fig. 1H). The egg reached the morula stage 4 hrs and 10 min after fertilization (Fig. 1I), blastula stage 5 hrs and $20 \mathrm{~min}$ after fertilization (Fig. 1J), and gastrula stage $6 \mathrm{hrs}$ and $40 \mathrm{~min}$ after fertilization (Fig. 1K). The embryo formed when the blastoderm covered the yolk at $11 \mathrm{hrs}$ and $45 \mathrm{~min}$ after fertilization (Fig. 1L), and optic vesicles, otocysts, and Kupffer's vesicles formed and the embryo started moving 20 hrs and 7 min after fertilization (Fig. 1M). Kupffer's vesicles disappeared, melanophores formed in the eyes, and the tail lengthened to separate from the yolk $22 \mathrm{hrs}$ and $10 \mathrm{~min}$ after fertilization (Fig. 1N). Melanophores in the eyes darkened and were also found along the spine in the shape of tree branches $42 \mathrm{hrs}$ and 50 min after fertilization. The membrane fin formed in the tail and blood started flowing from the heart across the yolk. The heartbeat at this stage was $68-70$ beats per minute (Fig. 10). Otoliths formed in the cephalus, tree branchshaped melanophores were widely present in the abdomen and the yolk, and the heart rate increased to $100-107$ beats per minute $70 \mathrm{hrs}$ and $26 \mathrm{~min}$ after fertilization. Larvae immediately prior to hatching started to emerge from the egg membrane from the head to start hatching (Fig. 1P).

\section{Larval morphological development}

The length of prelarvae immediately after hatching was 5.23-5.38 $\mathrm{mm}$ (average 5.31 $\pm 0.11 \mathrm{~mm}$ ). The mouth and anus were unopened, pectoral fin was formed, and membrane fin was formed from the upper cephalus to lower abdomen. Melanophores in the shape of tree branches formed from the cephalus and upper egg yolk across the center of the spine to the tail end (Fig. 2A).

The length of prelarvae 1 days after hatching was 5.97$6.20 \mathrm{~mm}$ (average $6.09 \pm 0.16 \mathrm{~mm}$ ). The mouth and anus were open, air bladder was formed, and they were able to swim. The membrane caudal fin was circular and tree branch-shaped melanophores were found in the upper air bladder. The location of anus at this stage was at $76.9 \%$ of total body length (Fig. 2B). 
The length of prelarvae 5 days after hatching was 7.24$7.56 \mathrm{~mm}$ (average $7.40 \pm 0.22 \mathrm{~mm}$ ). Their lower jaw was longer than their upper jaw and a soft ray started to form in the caudal fin. Melanophores were found where caudal fin rays formed (Fig. 2C).

The length of prelarvae 7 days after hatching was $7.8^{-}$ $8.27 \mathrm{~mm}$ (average $8.06 \pm 0.28 \mathrm{~mm}$ ). Melanophores in the shape of tree branches in the upper air bladder darkened and those in the caudal fin ray widened. In the caudal fin, 6 soft rays formed and the caudal notochord started to bend at $45^{\circ}$ (Fig. 2D).

The length of postlarvae 13 days after hatching was 9.93$11.2 \mathrm{~mm}$ (average $10.6 \pm 0.92 \mathrm{~mm}$ ). Melanophores in the shape of tree branches were found all over the body. The length of the lower jaw was greater than that of the upper jaw, and the membrane dorsal fin began to differentiate. There
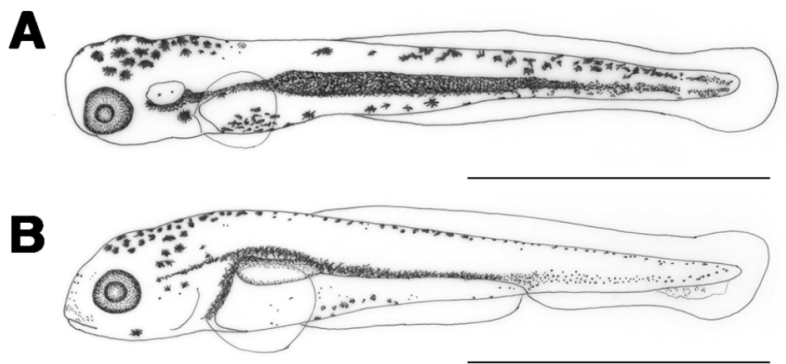

C

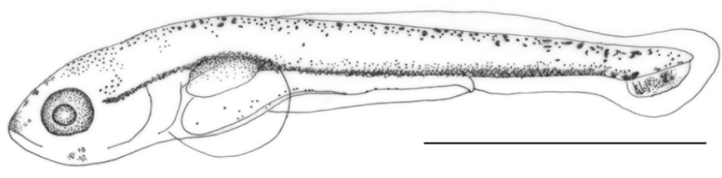

D

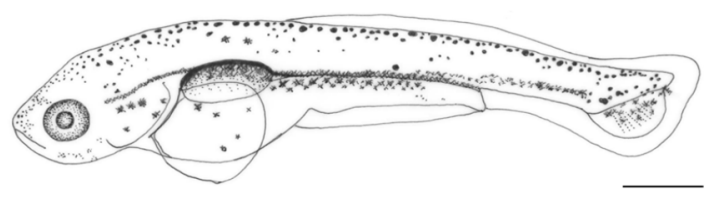

Fig. 2. Morphological development of prelarvae and postlarvae of carp, Cyprinus carpio. A: 5.23-5.38 $\mathrm{mm}$ total length (TL) newly hatched larvae; B: 5.97-6.20 mm TL, 1 days after hatching; C: 7.24$7.56 \mathrm{~mm}$ TL, 5 days after hatching; D: 7.86-8.27 $\mathrm{mm}$ TL, 7 days after hatching. Scale bars $=1.0 \mathrm{~mm}$. were 18 rays in the caudal fin and the location of the anus at this stage was at $78.1 \%$ of the total body length, which moved from the center to the back of the body (Fig. 3A).

The length of postlarvae 18 days after hatching was 11.9$13.9 \mathrm{~mm}$ (average 12.9 $\pm 1.40 \mathrm{~mm}$ ). Membrane dorsal and anal fins began to separate and rays started to form. Tree branch-shaped melanophores occurred in the dorsal fin. There
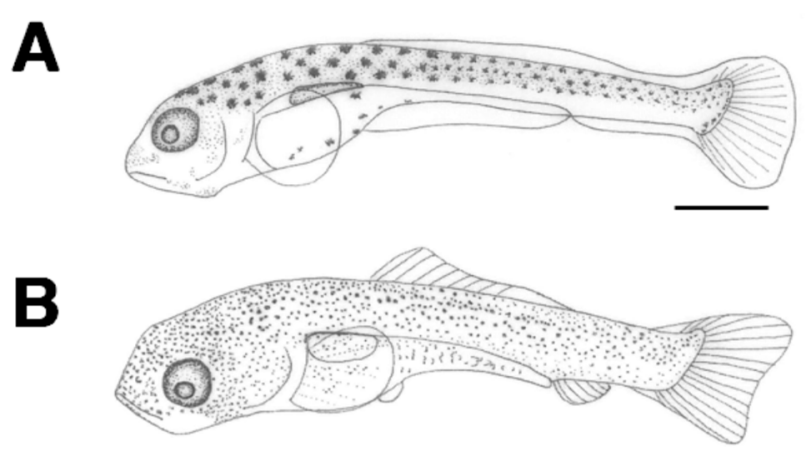

C

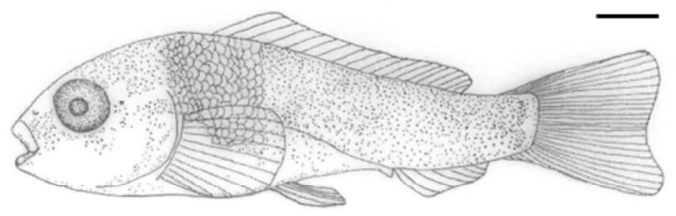

D

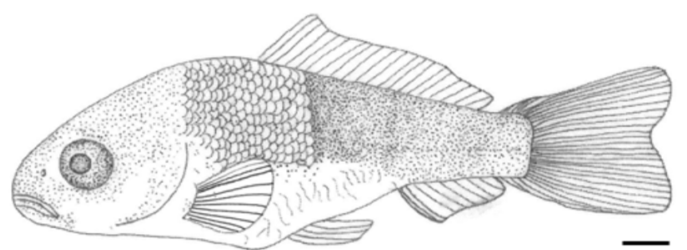

$E$

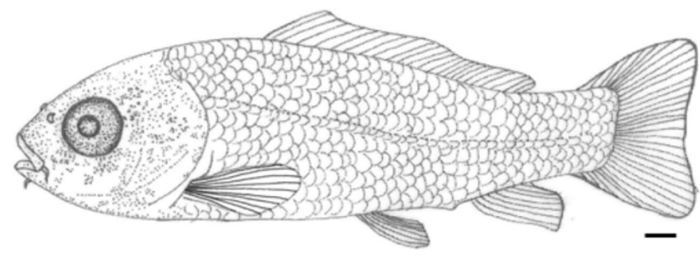

Fig. 3. Morphological development of the postlarvae and juveniles of carp, Cyprinus carpio. A: 9.93$11.2 \mathrm{~mm}$ TL, 13 days after hatching; B: 11.9-13.9 mm TL, 18 days after hatching; C: 16.4-21.1 mm TL, 23 days after hatching; D: 21.8-22.4 mm TL, 30 days after hatching; E: 29.9-30.2 mm TL, 35 days after hatching. Scale bars $=1.0 \mathrm{~mm}$. 
Table 1. The number of stem with every part of fin and barbel which is related to development of Carp, Cyprinus carpio

\begin{tabular}{ccccccccccc}
\hline \hline \multirow{2}{*}{$\begin{array}{c}\text { Meristic } \\
\text { characters }\end{array}$} & \multicolumn{8}{c}{ DAH (days after hatching) } \\
\cline { 2 - 9 } & 0 & 1 & 5 & 7 & 13 & 18 & 23 & 30 & 35 \\
\hline Ventral fin & - & - & - & - & - & - & 6 & 8 & 8 \\
Dorsal fin & - & - & - & - & - & 9 & 19 & 24 & 24 \\
Anal fin & - & - & - & - & - & 6 & 7 & 9 & 9 \\
Caudal fin & - & - & - & 6 & 18 & 18 & 32 & 32 & 32 \\
Barbel & - & - & - & - & - & - & - & 2 & 2 \\
\hline
\end{tabular}

were 9 fin rays in the dorsal fin and 6 in the anal fin (Fig. 3B).

The length of juvenile fish 23 days after hatching was 16.4-21.1 mm (average 18.7 $\pm 3.34 \mathrm{~mm}$ ). Scales formed from the top of the operculum to the anus and melanophores that previously covered the whole body now occurred in a speckled shape. The numbers of fin rays in each body part were increased to 6 in ventral fin, 19 in dorsal fin, 7 in anal fin, and 32 in caudal fin. The location of the anus at this stage was at $51.3 \%$ of the whole body length (Fig. 3C).

The length of juvenile fish, 30 days after hatching, was $21.8-22.4 \mathrm{~mm}$ (average $22.1 \pm 0.41 \mathrm{~mm}$ ). One pair of whiskers has formed and scales covered $2 / 3$ of the body. The numbers of fin rays increased to 8 in the ventral fin, 24 in the dorsal fin, and 9 in the anal fin (Table 1; Fig. 3D).

The length of juvenile fish 35 days after hatching was 29.9-30.2 mm (average 30.1 $\pm 0.13 \mathrm{~mm}$ ). Scales formed all over the body and the length of the upper jaw was greater than that of the lower jaw. Lateral lines were clearly visible and the location of the anus was at $60.4 \%$ of the body length, between the central and rear part of the body (Fig. 3E).

\section{DISCUSSION}

Spawning of C. carpio occurs amongst aquatic plants in shallow water by mature males and females at early dawn similar behavior is observed in C. carassius and C. cuvieri. Order Gobioniae (Cypriniformes), such as G. macrocephala, G. brevibarba, and M. koreensis, spawn in rapids with sand or pebbles, and Pungtungia herzi, P. tenuicorpa, and P. nigra parasitize the spawning ground of Coreoperca herzi reflecting differences in spawning habitats and behavior between species.

The average length of fertilized C. carpio eggs was $1.82 \pm 0.06 \mathrm{~mm}$, which is similar to that reported in Uchida (1939) with a diameter of $1.83 \mathrm{~mm}$, which was longer than that of C. carassius (Han et al., 2001a) of $1.57 \mathrm{~mm}$ diameter in the same order, G. macrocephala (Ko et al., 2011a) of $0.89 \mathrm{~mm}$ diameter in order Gobioninae, G. brevibarba (Ko et al., 2011b) with $1.24 \mathrm{~mm}$, M. koreensis (Kim et al., 2012) of $1.80 \mathrm{~mm}$, and R. oxycephalus (Han et al., 1999) of $1.80 \mathrm{~mm}$ in Leuciscinae, and shorter than Pseudorasbora parva (Han et al., 2001b) of $1.86 \mathrm{~mm}$ diameter, P. tenuicorpa (Ko et al., 2012) of $1.96 \mathrm{~mm}, P$. herzi (Lee et al., 2002) of $2.10 \mathrm{~mm}$, P. nigra (Lee et al., 2004) of $2.18 \mathrm{~mm}$, and Z. koreanus (Lee et al., 2013) of $3.09 \mathrm{~mm}$ in order Danioniae, reflecting differences in fertilized egg size between species and orders. The size of fertilized eggs is directly proportional to the size of postlarvae thus, smaller postlarvae had smaller fertilized eggs. Since the size of fertilized eggs is also directly related to incubation time and fecundity, it is closely related to the initial breeding strategy of each species, and for species in the same genus, with similar ecological statuses.

Optimum water temperature differed in fish species according to their life cycle and ecological characteristics; water temperature is an environmental factor affecting initial egg development, and larval growth and survival (Cho et al., 2015). Comparison of the incubation time required for the egg to hatch showed that carp required $70 \mathrm{hrs}$ and $26 \mathrm{~min}$ in average water temperatures of $20.0 \pm 0.05^{\circ} \mathrm{C}$, according to a study by Cole et al. (2004), the time required for hatching was $120 \mathrm{~h}$ at $18^{\circ} \mathrm{C}$, and 55 hours at $25^{\circ} \mathrm{C}$; 
thus the time required was lower at higher water temperatures. C. carassius (Han et al., 2001a) needed 75 hrs and 20 min at $22.4^{\circ} \mathrm{C}, R$. oxycephalus (Han et al., 1999) $88 \mathrm{hrs}$ and $40 \mathrm{~min}$ at $19.0^{\circ} \mathrm{C}$. P. nigra (Lee et al., 2004) required $189 \mathrm{hrs}$ in an average water temperature of $19.0^{\circ} \mathrm{C}, \mathrm{G} . \mathrm{ma}-$ crocephala (Ko et al., 2011a) needed $107 \mathrm{hrs}$ at $23.0^{\circ} \mathrm{C}$, and G. brevibarba (Ko et al., 2011b) $100 \mathrm{hrs}$ at $23.0^{\circ} \mathrm{C}$. P. tenuicorpa (Ko et al., 2012) required $168 \mathrm{hrs}$ in an average water temperature of $23.0^{\circ} \mathrm{C}, M$. koreensis (Kim et al., 2012) needed 29 hrs at $23.0^{\circ} \mathrm{C}$, and Z. koreanus (Lee et al., 2013) 68 hrs at $20.0-23.0^{\circ} \mathrm{C}$. P. herzi (Lee et al., 2002) required $185 \mathrm{hrs}$ and $55 \mathrm{~min}$ in an average water temperature of $19.0^{\circ} \mathrm{C}$ and $P$. parva (Han et al., 2001b) required $183 \mathrm{hrs}$ and $44 \mathrm{~min}$ at $17.6^{\circ} \mathrm{C}$, reflecting differences in incubation time according to water temperature.

Most Cyprinidae, including C. carpio, C. carassius, $R$. oxycephalus, M. koreensis, and Z. koreanus showed a trend of shortened incubation times in water temperatures higher than $20.0^{\circ} \mathrm{C}$. However, since $R$. oxycephalus, $P$. nigra, and $P$. herzi showed different incubation times when all species were bred in water temperatures of $19.0^{\circ} \mathrm{C}$, the phenomenon may be closely related to the fertilized egg size, the larger sized eggs requiring longer incubation periods, rather than being affected by water temperature, although its effects cannot be ignored (Sado \& Kimura, 2002; Lee et al., 2013).

A comparison of larval size immediately after hatching showed the average total length of $C$. carpio was $5.31 \pm$ $0.11 \mathrm{~mm}$, in contrast to a report by Uchida (1939) with a length of $5.00 \mathrm{~mm}$. In contrast, Cole et al. (2004) reported the average total length of hatching prelarvae to be 3.72 $\mathrm{mm}$, indicating that total length differs within species. Therefore, differences in the size of hatching prelarvae according to the regional distribution of carp should be studied.

The average total length of $C$. carpio was greater than that of P. parva (5.16 mm, Han et al., 2001b), M. koreensis
(2.20 mm, Kim et al., 2012), C. carassius (4.28 mm, Han et al., 2001a), G. macrocephala (4.60 mm, Ko et al., 2011a), R. oxycephalus (4.94 mm, Han et al., 1999), and smaller than that of G. brevibarba (5.50 mm, Ko et al., 2011b), P. herzi $(6.00 \mathrm{~mm}$, Lee et al., 2002), P. nigra $(5.82 \mathrm{~mm}$, Lee et al., 2004), P. tenuicorpa (8.60 mm, Ko et al., 2012), and Z. koreanus (10.3 mm, Lee et al., 2013).

The time required for absorption of the egg yolk after hatching differed, being 4-5 days for $C$. carpio, while $C$. carassius (Han et al., 2001a), in the same order, required 5 days; R. oxycephalus (Han et al., 1999) in the same order, Cypriniformes, required 6 days; P. herzi (Lee et al., 2002) required 7-8 days; P. parva (Han et al., 2001b), P. nigra (Lee et al., 2004), and G. brevibarba (Ko et al., 2011b) required 3 days; P. tenuicorpa (Ko et al., 2012) and $M$. koreensis (Kim et al., 2012) required 2 days; G. macrocephala (Ko et al., 2011a) required 4 days; and Z. koreanus (Lee et al., 2013) required 6 days.

The time of transition to postlarvae for C. carpio was at 5 days after hatching with an average total length of $7.40 \pm 0.22 \mathrm{~mm}$, in contrast to a report by Uchida (1939), who stated the transition to be at 10 days after hatching with an average total length of $8.50 \mathrm{~mm}$. The time of transition to postlarvae for C. carassius (Han et al., 2001a) was at 5 days after hatching with an average total length of $5.34 \mathrm{~mm}$, and for P. herzi (Lee et al., 2002) 13 days after hatching at $7.60 \mathrm{~mm}$, for P. parva (Han et al., 2001b) 7 days after hatching at $6.37 \mathrm{~mm}, R$. oxycephalus (Han et al., 1999) 6 days after hatching at $6.44 \mathrm{~mm}$, for P. nigra (Lee et al., 2004) 6 days after hatching at $8.06 \mathrm{~mm}$, for G. macrocephala (Ko et al., 2011a) 4 days after hatching at 6.10 $\mathrm{mm}$, for G. brevibarba (Ko et al., 2011b) 4 days after hatching at $7.40 \mathrm{~mm}$, for P. tenuicorpa (Ko et al., 2012) 2 days after hatching at $9.00 \mathrm{~mm}$, for M. koreensis (Kim et al., 2012) 4 days after hatching at $3.60 \mathrm{~mm}$, and $Z$. koreanus (Lee et al., 2013) 13 days after hatching at $16.9 \mathrm{~mm}$.

The time of transition to juvenile fish for $C$. carpio was 
Table 2. Comparison of early life historical characteristics of Cypriniformes

\begin{tabular}{|c|c|c|c|c|c|c|c|}
\hline Species & $\begin{array}{c}\text { Egg } \\
\text { diameter } \\
(\mathrm{mm})\end{array}$ & $\begin{array}{c}\text { Time of } \\
\text { hatching } \\
(* \mathrm{WT})\end{array}$ & $\begin{array}{l}\text { Days until } \\
\text { yolk sac } \\
\text { absorption } \\
\text { (day) }\end{array}$ & $\begin{array}{c}\text { Newly } \\
\text { hatched } \\
\text { larvae size } \\
\text { (mm) }\end{array}$ & $\begin{array}{c}\text { Postlarvae } \\
\text { size } \\
(\mathrm{mm})\end{array}$ & $\begin{array}{c}\text { Juveniles } \\
\text { size } \\
(\mathrm{mm})\end{array}$ & References \\
\hline \multirow{3}{*}{ Cyprinus carpio } & 1.82 & $\begin{array}{c}70 \text { h } 26 \text { mins } \\
\left(20.0^{\circ} \mathrm{C}\right)\end{array}$ & $4-5$ & 5.31 & 7.40 & 22.1 & Present study \\
\hline & 1.83 & - & - & - & 8.50 & - & Uchida, 1939 \\
\hline & - & $\begin{array}{c}120 \mathrm{~h}\left(18.0^{\circ} \mathrm{C}\right) \\
55 \mathrm{~h}\left(25^{\circ} \mathrm{C}\right)\end{array}$ & - & 3.72 & - & - & Cole et al., 2004 \\
\hline Carassius carassius & 1.57 & $\begin{array}{c}75 \mathrm{~h} 10 \mathrm{mins} \\
\left(22.4^{\circ} \mathrm{C}\right)\end{array}$ & 5 & 4.28 & 5.34 & 14.6 & Han et al., 2001a \\
\hline Gobiobotia macrocephala & 0.89 & $107 \mathrm{~h}\left(23.0^{\circ} \mathrm{C}\right)$ & 4 & 4.60 & 6.10 & 8.60 & Ko et al., 2011a \\
\hline Gobiobotia brevibarba & 1.24 & $100 \mathrm{~h}\left(23.0^{\circ} \mathrm{C}\right)$ & 3 & 5.50 & 7.40 & 9.90 & Ko et al., 2011b \\
\hline Microphysogobio koreensis & 1.80 & $29 \mathrm{~h}\left(23.0^{\circ} \mathrm{C}\right)$ & 2 & 2.20 & 3.60 & 6.50 & Kim et al., 2012 \\
\hline Rhynchocypris oxycephalus & 1.80 & $\begin{array}{c}88 \mathrm{~h} 40 \mathrm{mins} \\
\left(19.0^{\circ} \mathrm{C}\right)\end{array}$ & 6 & 4.94 & 6.44 & 18.7 & Han et al., 1999 \\
\hline Pseudorasbora parva & 1.86 & $\begin{array}{c}183 \mathrm{~h} 44 \text { mins } \\
\left(17.6^{\circ} \mathrm{C}\right)\end{array}$ & 3 & 5.16 & 6.37 & 14.6 & Han et al., 2001b \\
\hline $\begin{array}{c}\text { Pseudopungtungia } \\
\text { tenuicorpa }\end{array}$ & 1.96 & $168 \mathrm{~h}\left(23.0^{\circ} \mathrm{C}\right)$ & 2 & 8.60 & 9.00 & 10.6 & Ko et al., 2012 \\
\hline Pungtungia herzi & 2.10 & $\begin{array}{c}185 \text { h } 55 \text { mins } \\
\left(19.0^{\circ} \mathrm{C}\right)\end{array}$ & $7-8$ & 6.00 & 7.60 & 14.6 & Lee et al., 2002 \\
\hline Pseudopungtungia nigra & 2.18 & $189 \mathrm{~h}\left(19.0^{\circ} \mathrm{C}\right)$ & 3 & 5.82 & 8.06 & 14.5 & Lee et al., 2004 \\
\hline Zacco koreanus & 3.09 & $\begin{array}{c}68 \mathrm{~h} \\
\left(20.0-23.0^{\circ} \mathrm{C}\right)\end{array}$ & 6 & 10.3 & 16.9 & 20.0 & Lee et al., 2013 \\
\hline
\end{tabular}

at 30 days after hatching with an average total length of $22.1 \mathrm{~mm}$ and for $C$. carassius (Han et al., 2001a) 31 days after hatching at $14.6 \mathrm{~mm}$, reflecting little difference in terms of days after hatching, but a difference in the total length. The time of transition to juveniles for $P$. parva (Han et al., 2001b) was at 65 days after hatching with an average total length of $14.6 \mathrm{~mm}$, and P. herzi (Lee et al., 2002) was at 45 days after hatching with $14.6 \mathrm{~mm}$, and $R$. oxycephalus (Han et al., 1999) was at 80 days after hatching with $18.7 \mathrm{~mm}$, and for P. nigra (Lee et al., 2004) 44 days after hatching with $14.5 \mathrm{~mm}$, both of which took a longer time at a shorter total length to become juveniles than did C. carpio. The time of transition to juveniles for $G$ macrocephala (Ko et al., 2011a) was 15 days after hatching with an average total length of $8.60 \mathrm{~mm}$, for $G$. brevibarba (Ko et al., 2011b) 15 days after hatching at $9.90 \mathrm{~mm}$, for P. tenuicorpa (Ko et al., 2012) 10 days after hatching at $10.6 \mathrm{~mm}$, for M. koreensis (Kim et al., 2012) 20 days after hatching at $6.50 \mathrm{~mm}$, and for Z. koreanus (Lee et al., 2013) 27 days after hatching at $20.0 \mathrm{~mm}$, all of which took a shorter time and total length to become juveniles than did C. carpio(Table 2). 
These differences in total length according to development processes will become clearer with further research on the characteristics of their microhabitats, and ecological and physiological research (Kim et al., 2005b; Lee et al., 2013). Since $C$. carpio inhabits habitats with lower flow velocity, comparative research on different habitats should be conducted in the future to verify the differences in characteristics of habitats.

\section{REFERENCES}

Azim ME, Wahab MA (2003) Development of a duckweed-fed carp polyculture system in Bangladesh. Aquacult 218:425-438.

Blexter JHS (1974) The Early Life History of Fish. SpringVerlag Berlin 765p.

Chen ZY, Liu H, Li ZQ, Zang QY (2008) Development and characterization of monoclonal antibodies to spring viraemia of carp virus. Veterinary Immunology and Immunopathology 123:266-276.

Cho JK, Hong CK, Park JY, Son MH, Park CK, Park JM (2015) Effects of water temperature and salinity on the egg development and larvae of sevenband grouper, $E p$ inephelus septemfasciatus. Korean J Ichthyol 27:21-25.

Cole NJ, Hall TE, Martin CI, Chapman MA, Kobiyama A, Nihei Y, Watabe S, Johnson IA (2004) Temperature and the expression of myogenic regulatory factors (MRFs) and myosin heavy chain isoforms during embryogenesis in the common carp Cyprinus carpio L. J Experi Bio 207:4239-4248.

Cook AF, Wilson SW, Peter RE (1982) Development and validation of a carp growth hormone radio immunoassay. General and Comparative Endocrinology 50:335347.

Han KH, Jin DS, Yoo DJ, Beak SR, Hwang DS (2001a) The early life history of the crucian carp, Carassius auratus in Korea. Bull Yosu Nat Univ 16:379-387.

Han KH, Lee SH, Seo WI, Yoo DJ, Jin DS, Oh SH, Kim
CC (2001b) The spawning behavior and early life history of the false dace, Pseudorasbora parva in Korea. $\mathrm{J}$ of Ins for Basic Sci Yosu Nat Univ 3:67-76.

Han KH, Noh BY, Oh SH, Park JT, Cho JK, Seong KB (1999) Early life history and spawning behavior of Chinese minnow, Rhynchocypris oxycephalus reared in the laboratory. Korean J Ichthyol 11:177-183.

Kang SW (1990) Fresh Water Aquaculture. Seonjin-munhwasa pp. 315-316.

Kendall AW Jr, Ahlstrom EH, Moser HG (1984) Early life history stages of fishes and their characters. In: Moser, H.G. et al. (eds.), Ontogeny and Systematics of Fishes. Am Soc Ichthyol Herpetol Spec Publ 1:11-22, Allen Press, Lawrence, KS.

Kim CH, Yoon SW, Kim JG, Kim HT, Park JS, Park JY (2012) Embryonic development and early life history of the endangered species Microphysogobio koreensis (Pisces: Cyprinidae). Korean J Ichthyol 24:160-166.

Kim DS, Seo JE, Oh SY, Jo JY (1999) A production Method for two strains of common carp (Cyprinus carpio) using test-cross at a breeding trial. J of Aquacult 12: 163-165.

Kim IS, Choi Y, Lee CL, Lee YJ, Kim BJ, Kim JH (2005a) Illustrated Book of Korean Fishes. Kyo-Hak Publishing Co Ltd. Seoul. pp. 104-106.

Kim IS, Oh MK, Hosoya K (2005b) a new species of cyprinid fish, Zacco koreanus with redescription of Zacco temminckii (Cyprinidae) from Korea. Korean J Ichthyol 17:1-7.

Ko MH, Kim WJ, Park SY, Bang IC (2011a) Egg development and early life history of the endangered species Gobiobotia macrocephala (Cyprinidae). Korean J Ichthyol 23:198-205.

Ko MH, Park SY, Bang IC (2012) Egg development and early life history of the slender shinner, Pseudopungtungia tenuicorpa (Pisces: Cyprinidae). Korean J Ichthyol 24:48-55.

Ko MH, Park SY, Lee IL, Bang IC (2011b) Egg develop- 
ment and early life history of the endangered species Gobiobotia brevibarba (Pisces: Cyprinidae). Korean J Limnol 44:136-143.

Lee SH, Han KH, Hwang DS (2002) The early life history and spawning behavior of the Pungtungia herzi. J of Ins for Basic Sci Yosu Nat Univ 4:115-126.

Lee SH, Han KH, Yoon SM, Hwang DS, Yoo DJ, Lee CL, Kim IS, Son YM (2004) Early life history and spawning behavior of Pseudopungtungia nigra. Korean J Ichthyol 16:309-316.

Lee WO, Kim KH, Back JM, Song MY (2013) Egg development and early life history of Zacoo koreanus (Pisces: Cyprinidae). Korean J Ichthyol 25:200-207.

Nam MM, Yang HJ, Seo BK (1989) Morphological varia- tion of the crusian carp, Carassius auratus (Linnaeus) from yongnam area in Korea. Korean J Ichthyol 1:5463.

Sado T, Kimura S (2002) Descriptive morphology of the eggs, larvae, and juveniles of two cyprinid fishes belonging to the Zacco temminckii species' group. Ichthyol Res 49:245-252.

Uchida K (1939) The fishes of Tyosen. Part 1. Nematognathi, Eventognathi Bull Fish Exp Sta Gav Gener Tyosen $6456 \mathrm{p}$.

Yoon JM, Park SY (2006) Genetic comparison between crucian carp (Carassius auratus Linnaeus) and crucian carp (C. cuvieri Temminck and Schlegel). J Anim Sci \& Technol 48:637-650. 